\title{
Monitoring the Vegetation Communities on the Southern Slope of the Gutai Mountains on the Basis of Ecological Indices
}

\author{
Zorica VOŞGAN*, Lucia MIHALESCU, Roxana VIDICAN, Monica MARIAN, Stela JELEA, Oana MARE \\ ROȘCA
}

Department of Biology, Technical University of Cluj-Napoca, North University Center of Baia Mare, no.76, Victoriei Street, Baia Mare, Romania

${ }^{2}$ University of Agricultural Sciences and Veterinary Medicine, 3-5 Manastur Street, Cluj Napoca, Romania

*corresponding author, e-mail: zori_v13@yahoo.com

Bulletin USAMV series Agriculture 75(1)/2018

Print ISSN 1843-5246; Electronic ISSN 1843-5386

DOI 10.15835/buasvmcn-agr: 001117

\begin{abstract}
The analysis of the composition on the ecologic categories of the mountain region flora of the southern slope of the Gutai Mountains was carried out to monitor the adaptive and evolutionary process of the species. To achieve the spectrum of the ecological categories consideration was given to the preferences of the species against the main ecological factors: edaphic humidity (U), air temperature (T) and soil reaction (R). The results obtained are well-suited to the ecological character of the mountain flora, the stenoionic species illustrate the neutrophilic acid character of soils, with some peculiarities related to the type of mother rocks.
\end{abstract}

Key words: diversity, ecological, pasture

\section{Introduction}

The description and understanding of plant communities from mountain region is fundamental because provide valuable ecosystem services for sustainable development and human wellbeing (Gartzia et al., 2016). These ecosystems have undergone important changes over time due to some anthropogenic factors (land use through grazing, construction of ski resorts and associated infrastructure), but also due to climate change. Plant species distribution over a high geographical range is controlled by climatic factors, mainly temperature and rainfall (Gholinejad et al., 2012), but species distribution is related to edaphic factors. Climate fluctuations also generate floristic, structural and functional changes in vegetal communities (Pacurar et al., 2014) and the duration of these changes and their impact on the ecosystem is still unknown. The area of research falls within a continental-temperate climate with late spring and rainfall all year round. The analysis of the ecological categories within the mountain pasture flora has been carried out in this research, in order to monitor the adaptive and evolutionary process of the vegetal species and communities in the unity of their relations with the environmental factors. The objectives of this study are the realization of the ecological spectrum of the species of the vegetal communities in the mountain region and their correlation with the information regarding the natural environment, the age and intensity of the anthropic pressure, the qualitative and quantitative structure of the phytocoenoses.

\section{Materials and methods}

In order to analyze the composition of the flora ecological categories in the southern region of the Gutai Mountains, consideration was given to the preferences of the species against the main ecological factors: edaphic humidity (U), air temperature (T) and soil reaction (R). The spectrum of the ecological categories is based on the number of the species within each category, 
Table 1. Analysis of the categories of plants, grouped according to the main ecological indices

\begin{tabular}{|c|c|c|c|c|c|c|c|c|c|c|c|c|c|}
\hline & $\begin{array}{l}\text { logical } \\
\text { dices }\end{array}$ & 1 & 1.5 & 2 & 2.5 & 3 & 3.5 & 4 & 4.5 & 5 & 5.5 & 6 & 0 \\
\hline \multirow[t]{2}{*}{$\mathrm{U}$} & No.sp. & - & - & 7 & 8 & 28 & 7 & 17 & 13 & 7 & - & 6 & 14 \\
\hline & $\%$ & - & - & 6.54 & 7.47 & 26.16 & 6.54 & 15.88 & 12.14 & 6.54 & - & 5.6 & 13.08 \\
\hline \multirow{2}{*}{$\mathrm{T}$} & No. sp. & - & - & 6 & 6 & 51 & - & 3 & - & - & - & - & 41 \\
\hline & $\%$ & - & - & 5.6 & 5.6 & 47.66 & - & 2.8 & - & - & - & - & 38.31 \\
\hline \multirow[t]{2}{*}{$\mathrm{R}$} & No. sp. & 4 & - & 13 & 1 & 21 & - & 8 & - & - & - & - & 60 \\
\hline & $\%$ & 3.73 & - & 12.14 & 0.93 & 19.62 & - & 7.47 & - & - & - & - & 56 \\
\hline
\end{tabular}

related to the total number of species in the analyzed phytocoenoses.

\section{Results and discussions}

The ecologically analyzed floral composition highlights both the nature of the general climate and the ecotypes diversity in the mountainous region. The spectrum of the ecological categories has been established according to the share of the species with certain ecological valencies versus the factors $\mathrm{U}, \mathrm{T}, \mathrm{R}$. (Table 1 ).

Grouping the analyzed species according to the humidity regimen to which they are adapted, it was found a dominance of the mesophilic species (33.63\%), followed by the meso-hygrophilic ones (22.42\%). Lower proportions were recorded with hygrophilous, euridic and xero-mesophilic plants. Depending on the temperature, most species belong to the micro-mezoterm class (53.2\%), followed by euriterms (38.31\%) and far away by microterms. Considering the plants preferences for the chemical reaction of the soil, it was found that among the species present in the region, the well-represented euriionic (amphytolerant) dominated with 56\%, and among the stenoionic species, the higher values were shown by the acido-neutrophilic group (20.55\%), and even by the acidophilic one (12.14\%), thus reflecting the chemical reaction of soils in the studied region. This is due to the anthropogenic pressures exerted by the overexploitation of pastures through grazing and the lack of agro-ameliorative measures. The obtained results reveal, to a good extent, the ecological character of the flora, this being in close relation with the climate and the pedogenetic substrate.

\section{Conclusion}

The grassland flora in the southern region of the Gutai Mountains has a mesophilic, micromesotherm, eurionic to acid-neutrophil character. The results suggest that changes in mountain pastures reveal direct relationships with the current management practices and climatic trends. The knowledge of the ecological requirements of species helps to improve the agro-ameliorative measures for a higher economic yield.

\section{References}

1. Gartzia M, Perez-Cabello F, Bueno CG, Alados CL (2016). Physiognomic and physiologic changes in mountain grasslands in response to environmental and anthropogenic factors. Applied Geography: 66, 1-11.

2. Gholinejad,B, Farajollahi A, Pouzesh H (2012). Environmental factors affecting on distribution of plant communities in semiarid area (Case study: Kamyaran rangelands, Iran). Annals of Biolo gical Research, 3(8):3990-3993.

3. Pacurar F, Rotar I, Reif A, Vidican R, Stoian V, Gartner SM, Allen RB (2014). Impact of Climate on Vegetation Change in a Mountain Grassland - Succession and Fluctuation. Not Bot Horti Agrobot, 42(2):347-356. 